necessity of nationalization of India's power resources, to the usefulness of research institutes on power, plant industry, and to the creation of national councils of industrial and scientific research. His radical views and straightforward criticisms have not rendered him a persona grata either with the British officials who constitute the Central Government or with the Congress, but they are gradually finding acceptance with the public.

\section{Mr. T. A. Joyce, O.B.E.}

THE approaching retirement, to take effect early in August, is announced of Thomas Athol Joyce, deputy keeper in charge of the Sub-Department of Ethnography of the British Museum (Bloomsbury). Mr. Joyce was educated at Dulwich and Hertford College, Oxford. $\mathrm{He}_{\mathrm{e}}$ was appointed in 1902 to the staff of the British Museum in the Department of British and Medieval Antiquities and Ethnography, of which Mr. (later Sir) Charles Hercules Read was then keeper. Mr. Joyce during the Great War was attached to the War Office on the General Staff (Intelligence), attaining the honorary rank of captain, and being awarded the O.B.E. in 1918. In 1921, he was appointed deputy keeper of his department, and on its reorganization was placed in charge of the SubDepartment of Ethnography in 1932. In his departmental work, he had specialized in the ethnography of the peoples of Africa and the antiquities of America. His three books on the archæology of South America, Mexico and Central America, appearing between 1912 and 1916, in which the evidence available up to that time was analysed critically, secured his position as an authority among scholars in both the Old World and the New. Consequently Mr. Joyce was inevitably chosen to lead the expeditions sent by the British Museum to British Honduras in 1925 and succeeding years up to 1931, to excavate the ruined Mayan cities of that region. In addition to a large number of contributions to the publications of learned societies and the more serious of the journals devoted to the arts, such as the Connoisseur, Mr. Joyce was the author, in collaboration with Mr. E. Torday, of "Les Bushongo" (1910), of a valuable little book on Mayan Art (1927), and of the official guide to the ethnographical collections of the British Museum (1910). He held office as honorary secretary of the Royal Anthropological Institute in 1903-13, for two terms as vicepresident, and as president (1931-33), and was president of the Anthropological Section of the British Association in 1934.

\section{Memorial to Dr. W. J. S. Lockyer}

ON July 16, at the Norman Lockyer Observatory, Sidmouth, a memorial was unveiled to the late Dr. W. J. S. Lockyer, who was director of the Observatory, in succession to his father, Sir Norman Lockyer, from 1920 until his death in 1936. The unveiling was performed by Sir Francis McClean, a personal friend of Dr. Lockyer, well acquainted with the latter's manifold activities, such as photography and aeronautics in addition to his astronomical work.
Sir Robert Mond took the chair, and a speech was also made by Sir Richard Gregory who, after paying tribute to Dr. Lockyer's memory, spoke about the foundation and present position of the Observatory. The memorial (subscribed for by friends of the late director) consists first of a panel with a portrait of Dr. Lockyer in the centre surrounded by smaller portraits of those friends who have assisted in the administration and organization of the Observatory during his term of office. Beneath this panel is a cabinet containing Sir Norman Lockyer's insigmia and other records of his life and work. As the subscriptions were more than sufficient to supply these two articles the balance was put towards the new 'Oxford' recording microphotometer (mentioned in NaTURE of July 16, p. 108), which thus forms a part of the memorial, very suitably recognizing Lockyer's astronomical work at the Observatory. Half the cost of the microphotometer is being met by Sir Robert Mond and the other half by subseriptions to the memorial and from Observatory funds. The instrument is now completed and installed, so that the Observatory's equipment for measuring spectra is now brought up to the level of the principal observatories in Great Britsin and other countries.

\section{Record Non-Stop Formation Flight}

Leaving Cranwell at 4.15 a.m. on Thursday, July 7, four Vickers Wellesley aircraft, fitted with 'Bristol' Pegasus engines and Rotol constant-speed airscrews, flew non-stop for 32 hours. They arrived at Ismailia, Egypt, next day at 12.10 p.m., having covered a distance of 4,300 miles at an average ground-speed of 135 m.p.h. This achievement, which was part of the development work of the Long-Range Unit of the Royal Air Force, is the longest non-stop formation flight ever accomplished. A flight of this nature is an extreme test of the absolute reliability of the engines. The Pegasus engines employed were the medium-supercharged type, specially developed for economy of fuel consumption. They have to be capable of running continuously on very weak mixtures, which increases the flame temperatures in the cylinders, so that the pistons, valves, plugs, etc., are subjected to abnormally high thermal stresses. The average height during the flight was about 10,000 feet, which sets up a difficult combination of high engine gas temperatures and low air density on one hand, and operation at very low power in a cold atmosphere on the other. It is a tribute to the design, manufacture, and maintenance of these engines that they stood up to the exacting conditions of this flight, giving a continuous performance of more than a thousand horse-power for little more than a thousand pounds weight.

\section{'Round-the-World' Flight in Northern Latitude}

Mr. Howard Hughes, with Messrs. Connor and Thurlow, navigators, Stoddart, radio operator, and Lund, engineer, landed at New York on July 14, at 7.37 B.S.T. after having flown a circuit of the earth in the northern hemisphere, well above latitude

(Continued on page 167) 